\title{
Review: the charnockite problem, a twenty first century perspective
}

\author{
Samarendra Bhattacharya \\ Geological Studies Unit, Indian Statistical Institute, Calcutta, India; samar.bhattacharya@gmail.com
}

Received 11 December 2009; revised 12 January 2010; accepted 5 February 2010.

\section{ABSTRACT}

Beginning of the twentieth century was marked by coinage of a new rock name, Charnockite, first described as a hypersthene-bearing granite from Southern India. Since then charnockites have been described from most of the continents and mostly restricted to high-grade belts. Later half of the last century saw a lively debate over an igneous versus metamorphic origin. However, two factors acted as deterrents for the resolution of the debate. First, charnockites and associated rocks occur in a variety of different structural setting and display diverse field relations, attesting to possible different mode of origin. Second and possibly more important is the lack of consensus on the nomenclature of charnockites and associated rocks and this is commonly linked with the metamorphic versus magmatic perspective. Scanning the literature of this period makes one believe that both metamorphic and magmatic hypotheses are valid, but applicable to different field setting only. Before critically evaluating individual cases, it is imperative that a uniform approach in nomenclature should be agreed upon. It is proposed that name charnockite be adopted for any quartzofeldspathic rock with orthopyroxene, irrespective of its mode of occurrence, structural setting and mode of origin. The associated more mafic varieties, be better described as mafic granulite, rather than basic charnockite. For the patchy charnockites of east Gondwana (including parts of Peninsular India, Sri Lanka and Antarctica), metamorphic transformation from amphibolite facies gneiss, by two different mechanisms: $\mathrm{CO}_{2}$ ingress from deep level, and drop in fluid pressure, has been proposed. However, all such patchy occurrence is not amenable to explanation by metamorphic transformation. In some instances, migmatisation of older charnockitic rocks is evident. Also pro- gressive charnockitisation relating patchy charnockite to banded variety could be argued against on two counts: grain-size relation and time-relation. Larger bodies or bands have been explained as magmatic, but in many instances, from geochemical consideration alone. The compositional variation, commonly encountered in many high-grade belts, if not described in terms of field relation, may lead to wrong notions of magmatic differentiation of mantle-derived melts. Crustal melting of dry granulite facies source rocks has been proposed from geochemical and isotopic data of charnockitic intrusions. This model proposes high-temperature melting of previously dehydrated and dry granulite source rocks. However, tectonic perturbation subsequent to granulite facies metamorphism that might have been responsible for such high temperatures, is not well constrained in this model. Finally, with advent of highpressure dehydration-melting experiments in the nineties, dehydration-melting of mafic to intermediate composition, syn-kinematic with granulite facies metamorphism has been proposed.

Keywords: Incipient Growth; Progressive Charnockitisation; Plutonic Charnockite; Partial Melting; Plutonic Metamorphism

\section{INTRODUCTION}

Holland [1] first described charnockite from south India, as hypersthene-bearing granite; and Howie [2] introduced the concept of plutonic metamorphism: charnockite magma emplaced at lower crustal depth, resulting in slow recrystallisation under great heat and uniform pressure. Recent researches, particularly, dehydration melting under granulite conditions in the deep crust, both experimental and empirical results is compatible with the concept of plutonic metamorphism.

Since then charnockite has been described from most 
of the continents [3-9]. However, a variety of different mode of occurrence and structural setting, particularly the patchy occurrence first reported by Pichamuthu from Karnataka, south India [10] led to a lively debate over an igneous versus metamorphic origin. The first attempt for resolution of the charnockite problem was made by Ravich [11].

Another contentious issue relates to nomenclature, and to this day, this issue remains unresolved and no consensus among practicing earth scientists is a serious deterrent.

\section{NOMENCLATURE}

As more and more occurrences are reported, controversies on nomenclature cropped up and the IUGS classification, based on feldspar ratio, could not be uniformly implemented, even for the purported plutonic charnockites. On the one hand, many practicing earth scientists would use IUGS nomenclature, even for purported metamorphic charnockites [12-13]. It is noteworthy that not all the patchy occurrences are charnockite sensu stricto $[14,16,17]$. On the other hand, many of the reported plutons are enderbite or charno-enderbite, but described as charnockite by some workers [17-18]. Again, it has been noted from many granulite terrenes that large-scale bodies commonly include charnockite and enderbite, along with intermediate varieties, but are not distinguishable in the field $[15,19,20]$. Lack of consensus on charnockite nomenclature continues and some recent publications use various terms like charnockitic gneiss of tonalite-trondjhemite affinity, enderbite, enderbitic charnockite [21] and charnockites, charnockitic rocks, chemically quartz-monzodiorite, quartz monzonite, granodiorite and granite [22]. It is important to note that orthopyroxene also occurs in high-temperature pelitic granulites, which should not be confused with charnockitic rocks [23].

\section{SUMMARY:}

The only plausible solution could be a general name for any quartzofeldspathic rock with orthopyroxene as charnockite (except of course high aluminous pelites), irrespective of the mode of occurrence, structural setting and mineralogical-chemical variations within each occurrence; the associated more mafic varieties may be described as mafic granulite, rather than basic charnockite, as first proposed by us [17]. The chemical classification then may follow Streickeisen's scheme for common plutonic rocks and special names like enderbite etc may be omitted.

\section{MODE OF ORIGIN}

Naha et al. [24] noted that charnockitic rocks in south
India occur in a variety of different structural settings, attesting to different styles and time-relations. Since 1960, when Pichamuthu first described patchy charnockites from Kabbaldurga in south India, the focus shifted to metamorphic transformation. Moreover, Newton and Hansen [25] questioned the possibility of slow cooling (and hence magmatic charnockite) and recrystallization of relatively dry granitic to intermediate magma under deep seated conditions, as proposed by Holland and Lambert [26]. Lack of experimental evidence on the primary crystallization of orthopyroxene from such $\mathrm{H}_{2} \mathrm{O}$ under saturated $\mathrm{SiO}_{2}$ rich liquid was their main argument and this created a strong bias in favor of metamorphic transformation. However, Kramers and Ridley [27] considered the evolution of the fluid phase during crystallization in the presence of orthopyroxene, and showed that fluid saturation curve is reached at the field of high $\mathrm{CO}_{2} / \mathrm{H}_{2} \mathrm{O}$ ratios and hence fluid inclusions are predicted. They further argued that "the patchy distribution of amphibolite \& granulite facies TTG rocks in some highgrade terrains could be accounted for in this way". Melting experiments since the nineties, moreover, have highlighted the possibility of primary crystallization of orthopyroxene by dehydration melting reactions in the deep crust.

\subsection{Metamorphic Transformation}

From many localities in south India and Sri Lanka, "patchy" charnockites have been described as "arrested growth", "in situ" charnockites or charnockitisation of amphibolite facies gneisses [28-39].

Two suggested mechanisms of this transformation: $\mathrm{CO}_{2}$-influx and drop in fluid pressure are reviewed in the following paragraphs.

Influx of $\mathrm{CO}_{2}$ rich fluid from deep mantle source along structural weak zones has been proposed by several workers $[25,28,29,32,33,40]$. and Newton [15] mentioned three criteria for recognition of charnockitisation by $\mathrm{CO}_{2}$ influx, namely, 1) diffuseness of patchy alteration, unlike discrete veins; 2 ) occurrences closely associated with warping of foliation or dilation cracks; 3 ) open system alteration- often loss of mafic constituents and gain of $\mathrm{Na}$ and $\mathrm{Si} ; \mathrm{Y}$ and sometimes $\mathrm{Rb}$ are characteristically depleted. Some of these criteria are not ubiquitous, as argued by Bhattacharya and co-workers [14,16, 17]. From Kerala and from Chilka area of the Eastern Ghats belt, these workers have argued that, 1) diffuse boundaries of the charnockite patches could have been produced by migmatisation of older charnockitic bodies by a granitic melt; 2) at Elavattum and Kottavattum quarries in Kerala, the apparent disposition along conjugate fractures [41], are actually disrupted segments of fold limbs (Figure 7 in Reference [14]). In Chilka Lake area the charnockite patches occur as elongate bodies parallel to sub horizontal $F_{3}$ fold axis and along shear 
planes with sub horizontal direction of maximum stretching; hence these weak zones are shallow structures and cannot act as channelways for fluid ingress from deeper levels. From the classical area of south India, Kabbaldurga, Bhattacharya and co-workers argued that the charnockite patches are usually not emplaced along the system of fractures, that are common in this region; and 3) four varieties of Peninsular gneisses: granite, trondhjemite, granodiorite and tonalite and three varieties of charnockite: granite, trondhjemite and tonalite are recognized in the quarry and charnockite patches occur within all varieties of peninsular gneisses; hence chemical similarity between close-pairs, cited as evidence of in- situ transformation by several workers, could be fortuitous [17]. The reported abundance of $\mathrm{CO}_{2}$-rich fluid inclusions in patchy charnockites has been cited as evidence for the process of charnockitization by fluid- streaming [42] But Sen and Bhattacharya [16] argued that $\mathrm{CO}_{2}$-enriched fluid inclusions may be due to preferential loss of $\mathrm{H}_{2} \mathrm{O}$ by crystal plastic deformation and/or open system processes, as suggested by Hollister [43] and Buick and Holland [44]. For the patchy charnockites in the Eastern Ghats belt, $\mathrm{CO}_{2}$-rich fluid streaming was also assumed by several workers [45-47]. But the possibility of large-scale influx of $\mathrm{CO}_{2}$-rich fluids in the Eastern Ghats was ruled out by several workers $[48,49]$. Also deep mantle source of $\mathrm{CO}_{2}$-rich fluid is not evident, while Bhowmik et al. [49] presented isotopic evidence of local sedimentary source (calc-granulites) in a granulite suite from the Eastern Ghats belt.

Raith and Srikantappa [41] proposed an alternative mechanism of this transformation. According to this hypothesis, arrested charnockitization is internally controlled; during near-isothermal uplift, the release of carbonic fluids from decrepitating inclusions in the host gneiss into developing fracture zones, resulting in a change in fluid regime and development of an initial fluid-pressure gradient, triggering the dehydration reaction. What is common, however, between the two hypotheses, is development of "arrested charnockite" in structural weak zones. For the Kabbaldurga occurrence, Bhattacharya and Sen [17] pointed out that "charnockite veins at Kabbal are usually not emplaced along the system of fractures that are common in this region."

Time relations between charnockites and enclosing gneisses, as also between patchy occurrence and massive bodies, are important constraints, for validating or otherwise of the hypothesis of in-situ transformation. Naha et al. [24] pointed out that charnockites of Dharwar craton have formed in at least two distinct phases separated in time and possibly by different mode of origin. And Bhattacharya and Sen [17] pointed out that "patchy charnockites seen in Kerala and in the Eastern Ghats are mostly non-pegmatitic"; "the coarser-grained patches could very well be modified versions of the smaller patches"; and "... are basically earlier than the enclosing gneisses". It is imperative, therefore, to consider individual cases of "patchy charnockite", in terms of field relations and if possible, in terms of isotopic age relations. For the Chilka Lake case in the Eastern Ghats belt, Bhattacharya et al [50] reported older zircons in the patchy charnockite to those of the host leptynite/granite gneiss.

Another point of contention is the proposed link between patchy charnockite and massive charnockite, particularly in South India. Srikantappa et al [34] proposed progressive charnockitisation, from some locales in the Kerala Khondalite belt. But Sen and Bhattacharya [15] argued that grain-size relation between smaller patches and adjacent larger bands (supposedly final product) does not support this hypothesis. Sen and Bhattacharya [15] further argued on the evidence of field relation between them, that larger bands are actually older. On the other hand, the proposed genetic link between the incipient/arrested charnockite of the transition zone in South India to regional scale granulites (massive charnockite), is strongly influenced by the $\mathrm{CO}_{2}$-influx hypothesis [19,29,31-33,51]. According to this model ascent of the carbonic fluid front to higher crustal levels, results in pervasive fluid flow and wholescale granulitization of the deeper crustal domains. However, Raith and Srikantappa [41] argued on the evidence of field relations, petrological, geochemical and isotopic data, that development of arrested charnockites is a late-stage phenomenon; and regional-scale granulites could have been generated by dehydration melting processes.

\section{SUMMARY:}

Proposed hypothesis of charnockitisation, either by $\mathrm{CO}_{2}$ influx or drop in fluid pressure, could indeed be applicable for individual cases; but each would require additional data pertaining to structural setting and field structural data attesting to time relation. Additionally, isotopic data would resolve the issue in favor or against the hypothesis of progressive charnockitisation. It is emphasized here that patchy occurrence itself should not be taken as prototypes of incipient charnockite.

\subsection{Magmatic Origin}

Since Howie [2] proposed the hypothesis of plutonic metamorphism, large-scale charnockitic rocks have been described from many granulite terrenes [20-22,52-57]. Subba Rao and Divakara Rao [53] described charnockitic rocks of intrusive origin from Eastern Ghats Belt, and identified two groups, namely basic granulite and charnockite. From geochemical angle, these authors proposed that protoliths of these charnockitic rocks are the fractionated products of a melt, which was derived from metasomatised mantle, and that these were affected 
by a depletion event probably coeval with granulite facies metamorphism. Although, two groups were said to be identified "based upon field relations and chemistry", the actual field relation between basic granulite and charnockite is not described in this publication. Moreover, as noted earlier by several workers, local structural setting and sample locations are important criteria, and without these information, the applicability of the mantle melting model proposed by these authors can be questioned. In this context, it is important to note that from detailed field mapping and structural analysis in the Chilka Lake area of the Eastern Ghats belt, India, Bhattacharya et al [57] argued that "certainly an igneous protolith which has suffered granulite facies metamorphism (as evidenced by inter-layered basic granulites) is a distinct possibility". It is unfortunate that some workers concluded that in the Eastern Ghats belt, age relations may be deduced from field relations, but neither do they present any data, nor refer to published information; hence their conclusion that "intruding magmas are either mantle-derived (basic granulites, enderbites and charnockites with crustal contribution)...." remains questionable [58]. Bhattacharya and co-workers described two types of field relations between charnockitic rocks and metapelitic rocks. First type is the interbanding of the two lithologies; the time relation is uncertain, though both may have undergone granulite facies metamorphism together [57,59]. The other type of field relation between the two lithologies is all the more complex; large-scale bodies of charnockitic rocks usually occur as separate exposures, and no contact between the two could be observed; no pelitic enclaves were observed in charnockites. Only on the basis of the sequence of deformation structure, a tentative correlation has been proposed: mafic granulite, occurring as folded enclaves in charnockite, could be correlated to intrafolial folds in pelitic granulites [57,60]. Dobmeier and Raith [13] also observed that "since the enderbitic and metasedimentary rocks have identical structural histories, the emplacement (of enderbitic/tonalitic magma) happened prior to the discernible deformation..." in the Chilka Lake area.

Magmatic origin of charnockite is also proposed by several workers in the nineties. Kilpatrick and Ellis [7] described Charnockite Magma Type, or C-type, from different areas, with distinctive geochemical signatures. This C-type magma was considered to be derived by melting of a dry granulite source. It should be noted that this C-type magma is not strictly charnockite sensu stricto, but varies between charno-enderbite and charnockite (see $\mathrm{K}_{2} \mathrm{O} / \mathrm{Na}_{2} \mathrm{O}$ ratios and $\mathrm{SiO}_{2}$ values in Table 1 of Reference [7]). Also the melting here is considered to have been post-granulite facies metamorphism and a crustal-melting event. Melting of dry granulite-facies source rocks, for Antarctican charnockites, was also proposed by some workers from geochemical and iso- topic data $[20,55,61]$. On the other hand, Sheraton et al. [54] argued that more mafic varieties may be largely mantle-derived. It is important to note that these reports on Antarctican charnockites show a range of composition from quartz monzodiorite through granodiorite to adamelite. Hence, discrimination between charnockite and enderbite magma, in massif-type or intrusive charnockite, was considered inappropriate by these authors. This model proposes high-temperature melting of previously dehydrated and dry granulite source rocks. But tectonic perturbation subsequent to granulite facies metamorphism that might have been responsible for such high-temperatures is not well constrained in this model.

A partial melting interpretation for vein type charnockite was advocated by Hansen and Stuk [62], and these authors reported orthopyroxene-bearing leucosomes, of tonalitic to granodioritic composition, within mafic bodies of granulite facies rocks from California.

Finally, melting experiments, particularly dehydration-melting experiments of mafic to intermediate rocks in the nineties have added a new dimension to the problem of charnockite genesis [63-66]. These experiments demonstrate a) significant melting at 8 to $10 \mathrm{kbar}$ and temperatures in excess of $850^{\circ} \mathrm{C}$; these values are commonly recorded from many granulite terrains; b) the residual assemblage of two-pyroxene-plagioclase-quartz \pm garnet, clearly resemble mafic granulite, that are frequently found associated with massif-type charnockite; c) melt compositions in hornblende-dehydration melting range from tonalite-granodiorite-trondjhemite, while hornblende-biotite combined melting produced granitic melts.

From the classic area, Kabbaldurga, in South India, Bhattacharya and Sen [17] presented a new interpretation of vein type charnockite. These authors proposed hornblende and biotite dehydration melting in two types of mafic granulites observed in the area, producing two types of charnockitic vein, of tonalitic and granitic compositions respectively. Besides the field features, such as orthopyroxene-bearing leucosomes within mafic granulite enclaves in the peninsular gneiss; these authors presented comparative mineral compositions in the charnockite veins and mafic granulite enclaves and bulk compositions of the charnockite veins, and these are compatible with the results of experimental melting, referred to above.

For the massif-type charnockite in the Eastern Ghats belt, India, Kar et al. [56] proposed a hornblende- dehydration melting in mafic rocks, now occurring as cognate xenoliths, under granulite facies conditions. Additionally these authors reported two types of mafic granulites, namely prograde hornblende-bearing mafic granulite, interpreted as restitic granulite and two-pyroxene mafic granulite, interpreted as peritectic segregations. 
And unlike Subba Rao and Divakara Rao's [53] mantle-melting model for the Eastern Ghats charnockite, these authors described a crustal melting phenomenon, coeval with granulite facies metamorphism. From pressure-temperature estimates and P-T path constraints, these authors further argued that melting could have occurred in thickened continental crust undergoing decompression. Bhattacharya et al. [67] established the link between partial melting and granulite facies metamorphism with isotopic data. Kar et al. [56] further pointed out that trace element partitioning in dehydration melting is likely to be complex, because incongruent melting reactions result in two sets of solid mineral phases, residual and peritectic [68]. Hence quantitative modeling is inappropriate when the process involves reactions producing a variety of solid peritectic phases. Trace element partitioning then could be considered as a two stage process; to some extent correlated with different degrees of partial melting. At low degree of melting the main process is melt-restite separation, whereas at higher degrees of melting peritectic-melt separation becomes more important [69-71].

\section{SUMMARY:}

Although magmatic origin of charnockites, particularly for the large scale bodies, are evident in many cases, the question relating to either mantle-melting or crustal melting and in case of crustal melting, the actual melting process and conditions remain debatable in many cases. Dehydration-melting in mafic to intermediate rocks under granulite facies conditions could be the most potential hypothesis for the massif-type charnockite, provided prograde hornblende/biotite bearing mafic granulite enclaves are observed. Thus the concept of plutonic metamorphism may return with new vigor.

\section{REFERENCES}

[1] Holland, T.H. (1900) The charnockite series, a group of Archaean hypersthenic rocks in Peninsular India. Memoirs of the Geological Survey of India, 28, 119-249.

[2] Howie, R.A. (1954) The geochemistry of the charnockite series of Madras, India. Transactions of the Royal Society of Edinburgh, 62, 725-768.

[3] De Ward, D. (1969) The occurrence of charnockite in the Adirondacks: A note on the origin and definition of charnockite. American Journal of Science, 267, 983-987.

[4] Duchesne, J.C., Caruba, R. and Iacconi, P. (1987) Zircon in charnockitic rocks from Rogaland (Southwest Norway): Petrogenetic implication. Lithos, 20(5), 357-368.

[5] Condie, K.C. and Allen, P. (1984) Origin of Archaean charnockites from southern India. In: Kroner, A., ed., Archaean Geochemistry, Springer, Berlin, 182-203.

[6] Hubbard, F.H. and Whitley, J.E. (1979) REE in charnockite and associated rocks, southwest Sweden. Lithos, 12(1), 1-11.

[7] Kilpatrick, J.A., Ellis, D.J. and Young, D.N. (1990) Field aspects of the Ardery charnockitic intrusions, Windmill
Islands, Antarctica. A dynamic magma chamber. Geological Society of Australia Abstracts, 25, 290.

[8] Sheraton, J.W. (1982) Origin of charnockitic rocks of MacRobertson Land. In. Craddock, C., ed., Antarctic Geoscience, Madison University of Wisconsin Press, 489-497.

[9] Schumacher, R. and Faulhaber, S. (1994) Summary and discussion of $P-T$ estimates from garnet-pyroxene-plagioclase-quartz-bearing granulite facies rocks from Sri Lanka. Precambrian Research, 66(1-4), 295-308.

[10] Pichamuthu, C.S. (1960) Charnockite in the making. Nature, 188, 135-136.

[11] Ravich, M.G. (1972) The charnockite problem. In. Adie, R. J., ed., Antarctic Geology and Geophysics, Scandinavian University Books, Oslo, 523-526.

[12] Raith, M and Srikantappa, C. (1993) Arrested charnockite formation at Kottavattam, southern India. Journal of Metamorphic Geology, 11, 815-832.

[13] Dobmeier, C. and Raith, M. (2000) On the origin of "arrested" charnokitization in the Chilka Lake area, Eastern Ghats Belt, India: A reappraisal. Geological Magazine, 137, 27-37.

[14] Bhattacharya, S., Sen, S.K. and Acharyya, A. (1993) Structural evidence supporting a remnant origin of patchy charnockites in the Chilka Lake area, India. Geological Magazine, 130(3), 363-368.

[15] Newton, R. C. (1992) Charnockitic alteration: Evidence for $\mathrm{CO}_{2}$ infiltration in granulite facies metamorphism. Journal of Metamorphic Geology, 10, 383-400.

[16] Sen, S.K. and Bhattacharya, S. (1993) Patchy charnockites from south Kerala-nascent growths or modified relicts? Indian Minerals, 47, 103-112.

[17] Bhattacharya, S. and Sen, S.K. (2000) New insights into the origin of Kabbaldurga charnockites, Karnataka, South India. Gondwana Research, 3, 489-506.

[18] Rao, A.T. and Vijaykumar, V. (1992) Chemical petrology of charnockites from the Eastern Ghats granulite province, India. In: Kyriakidis, A.B., ed., High Grade Metamorphics, Theophrastus Publications, 217-235.

[19] Prasad, K.S.S., Rao, K.L.N. and Murty, M.S. (1992) Charnockites of Obachettapalem, Prakasam district, South India. In: Kyriakidis, A.B., ed., High Grade Metamorphics, Theophrastus Publications, 237-261.

[20] Young, D.N., Zhao, J.X., Ellis, D.J. and McCulloch, M.T., (1997) Geochemical and Sr-Nd isotopic mapping of source provinces for the Mawson charnockites, east Antarctica: implications for Proterozoic tectonics and Gondwana reconstruction. Precambrian Research, 86, $1-19$.

[21] Santosh, M., Yokoyama, K. and Acharyya, S.K. (2004) Geochronology and tectonic evolution of Karimnagar and Bhopalpatnam Granulite belts, Central India. Gondwana Research, 7, 501-518.

[22] Mendes, J.C., Medeiros, S.R., McReath, I. and Pinheiro de Campos, C.M. (2005) Cambro-Ordovician magmatism in SE Brazil: U-Pb and Rb-Sr ages, combined with $\mathrm{Sr}$ and $\mathrm{Nd}$ isotopic data of charnockitic rocks from the Varzea Alegre Complex. Gondwana Research, 8, 337346.

[23] Raith, M., Karmakar, S. and Brown, M. (1997) Ultrahigh temperature metamorphism and multi-stage decompressional evolution of sapphirine granulites from the 
Palni Hill Ranges, south India. Journal of Metamorphic Geology, 15, 379-399.

[24] Naha, K., Srinivasan, R. and Jayaram, S. (1993) Structural relations of charnockites of the Archaean Dharwar craton, southern India. Journal of Metamorphic Geology, 11, 889-895.

[25] Newton, R.C. and Hansen, E.C. (1983) The origin of Proterozoic and late Archaean charnockites-evidence from field relations and experimental petrology. Geological Society of America Memorials, 161, 167-178.

[26] Holland, J.G. and Lambart, R.S.J. (1975) The chemistry and origin of the Lewisian gneisses of the Scottish mainland: the Scourie and Inver assemblages and sub crustal accretion. Precambrian Research, 2(2), 161-188.

[27] Kramers, J.D. and Ridley, J.R. (1989) Can Archaean granulites be direct crystallization from a sialic magma layer? Geology, 17(5), 442-445.

[28] Janardhan, A.S., Newton, R.C. and Smith, J.V. (1979) Ancient crustal metamorphism at low $\mathrm{pH}_{2} \mathrm{O}$ : Charnockite formation at Kabbaldurga, south India. Nature, 278, 511-514.

[29] Janardhan, A.S., Newton, R.C. and Hansen, E.C. (1982) The transformation of amphibolite facies gneiss to charnockite in southern Karnataka and northern Tamil Nadu, India. Contributions to Mineralogy and Petrology, 79, 130-149.

[30] Janardhan, A.S., Jayananda, M. and Shankara, M.A. (1994) Formation and tectonic evolution of granulites from Biligirirangam and Nilgiri Hills, south India: Geochemical and isotopic constraints. Journal of the Geological Society of India, 44, 27-40.

[31] Friend, C.R.L. (1981) Charnockite and granite formation and influx of $\mathrm{CO}_{2}$ at Kabbaldurga. Nature, 294, 550-552.

[32] Hansen, E.C., Newton, R.C. and Janardhan, A.S. (1984) Fluid inclusions in rocks from amphibolite-facies gneiss to charnockite progression in southern Karnataka, India: direct evidence concerning the fluids of granulite metamorphism. Journal of Metamorphic Geology, 2, 249-264.

[33] Hansen, E.C., Janardhan, A.S., Newton, R.C., Prame, W.K.B. and Kumar, G.R.R. (1987) Arrested charnockite formation in southern India and Sri Lanka. Contributions to Mineralogy and Petrology, 96, 225-244.

[34] Srikantappa, C., Raith, M. and Spiering, B. (1985) Progressive charnockitization of a leptynite-khondalite suite in southern Kerala, India: Evidence for formation of charnockites through a decrease in fluid pressure? Journal of the Geological Society of India, 26, 62-83.

[35] Srikantappa, C., Raith, M. and Touret, J.L.R. (1991) Synmetamorphic, high-density carbonic fluids in the lower crust: Evidence from the Nilgiri granulites, southern India. Journal of Petrology, 33(4), 733-760.

[36] Raith, M. Stahle, H.J. and Hoernes, S. (1988) Kabbaldurga-type charnockitization: a local phenomenon in the granulite to amphibolite grade transition zone. Journal of the Geological Society of India, 31, 116-117.

[37] Raith, M., Srikantappa, C., Ashamanjeri, K.G. and Spiering, B. (1990) The granulite terrene of the Nilgiri Hills (southern India): Characterization of high-grade metamorphism. In: Vielzeuf, D. and Vidal, P., ed., Granulites and Crustal Evolution, NATO ASI Series C, Kluwer Academic Publishers, Dordrecht, 311, 339-365.

[38] Yoshida, M. and Santosh, M. (1994) A tectonic perspec- tive of incipient charnockites in East Gondwana. Precambrian Research, 66(1-4), 379-392.

[39] Harley, S.L. and Santosh, M. (1995) Wollastonite at Nuliyam, Kerala, South India: A reassessment of $\mathrm{CO}_{2}$ infiltration and charnockite formation at a classic locality. Contributions to Mineralogy and Petrology, 120, 83-94.

[40] Condie, K.C., Bowling, G.P. and Allen, P. (1986) Origin of granites in an Archaean high-grade terrene, southern India. Contributions to Mineralogy and Petrology, 92, 93-103.

[41] Raith, M and Srikantappa, C. (1993) Arrested charnockite formation at Kottavattam, southern India. Journal of Metamorphic Geology, 11, 815-832.

[42] Santosh, M., Jackson, D.H., Mattey, D.P. and Harris, N.B.W. (1988) Carbon Stable Isotopes of fluid inclusions in the granulites of southern Kerala: Implications for the source of $\mathrm{CO}_{2}$. Journal of the Geological Society of India, 32, 477-493.

[43] Hollister, L.S. (1993) The role of melt in the uplift and exhumation of orogenic belts. Chemical Geology, 108, 31-48.

[44] Buick, I.S. and Holland, T.J.B. (1991) The nature and distribution of fluids during Amphibolite facies metamorphism, Naxos (Greece). Journal of Metamorphic Geology, 9, 301-314.

[45] Halden, N.M., Bowes, D.R. and Dash, B. (1982) Structural evolution of migmatites in a granulite facies terrene Precambrian crystalline complex of Angul, Orissa, India. Transactions of the Royal Society of Edinburgh, Earth Science, 73, 109-118.

[46] Paul, D.K., Burman, T.R., McNaughton, N.J., Fletcher, I.R., Potts, R.J., Ramakrishnan, M. and Augustine, P.F (1990) Archaean-Proterozoic evolution of Indian charnockites: Isotopic and geochemical evidence from granulites of the Eastern Ghats Belt. Journal of Geology, 98, 253-263.

[47] Rajesham, T., Nagarajan, K., Murti, K.S., Shirahata, H. and Yoshida, M. (1994) Incipient charnockitisation in Eastern Ghats terrain of Vizianagram area, Andhra Pradesh. Workshop on Eastern Ghats Mobile Belt, Vishakapatnam, 43.

[48] Bhattacharya, A. and Sen, S.K. (1991) Pressure, temperature and fluid regime in selected granulites tracts of the Eastern Ghats of India. Proceedings Seminar on Composition and Evolution of High-Grade Gneiss Terrains, IGCP Project 304, Lower Crustal Process, Kandy.

[49] Bhowmik, S.K., Dasgupta, S., Hoernes, S. and Bhattacharya, P.K. (1995) Extremely high-temperature calcareous granulites from the Eastern Ghats, India: Evidence for isobaric cooling, fluid buffering, and terminal channelized fluid flow. European Journal of Mineralogy, 7, 689-703.

[50] Bhattacharya, S., Deomurari, M.P. and Teixeira, W. (2003) Grenvillian thermal event and remnant charnockite: Isotopic evidence from the Chilka Lake granulite-migmatite suite in the Eastern Ghats belt, India. Proceedings of the Indian Academy of Sciences (Earth and Planetary Science), 111, 391-399.

[51] Harris, N.B.W., Holt, R.W. and Drury, S.A. (1982) Geobarometry, geothermometry and the Late Archaean geotherms from the granulite facies terrain in South India. Journal of Geology, 90, 509-527. 
[52] Sriramdas, A. and Rao, A.T. (1979) Charnockites of Vishakapatnam, Andhra Pradesh. Journal of the Geological Society of India, 20, 512-517.

[53] Rao, M.V.S. and Rao, V.D. (1988) Chemical constraints on the origin of the charnockites in the Eastern Ghats mobile belt, India. Chemical Geology, 69(1-2), 37-48.

[54] Sheraton, J.W., Black, L.P. and Tindle, A.G. (1992) Petrogenesis of plutonic rocks in a Proterozoic granulite facies terrene-The Bunger Hills, East Antarctica. Chemical Geology, 97, 163-198.

[55] Zhao, J., Ellis, D.J., Kilpatrick, J.A. and McCulloch, M.T. (1997) Geochemical and Sr-Nd isotopic study of charnockites and related rocks in the northern Prince Charles Mountain, East Antarctica. Precambrian Research, 81, 37-66.

[56] Kar, R., Bhattacharya, S. and Sheraton, J.W. (2003) Hornblende-dehydration melting in mafic rocks and the link between massif-type charnockite and associated granulites, Eastern Ghats Granulite Belt, India. Contributions to Mineralogy and Petrology, 145, 707-729.

[57] Bhattacharya, S., Sen, S.K. and Acharyya, A. (1994) The structural setting of the Chilka Lake granulite-migmatiteanorthosite suite with emphasis on time relation of charnockites. Precambrian Research, 66, 393-409.

[58] Rickers, K., Mezger, K. and Raith, M. (2001) Evolution of the continental crust in the Proterozoic Eastern Ghats Belt, India and new constraints for Rodinia reconstruction: Implications from $\mathrm{Sm}-\mathrm{Nd}, \mathrm{Rb}-\mathrm{Sr}$ and $\mathrm{Pb}-\mathrm{Pb}$ isotopes. Precambrian Research, 112, 183-210.

[59] Bhattacharya, S. (2003) Dehydration melting in mafic rocks in the Eastern Ghats Belt, India: Implications for variable composition of charnockitic melt and heterogeneity of source rocks. Memoirs of the Geological Society of India, 52, 131-144.

[60] Bhattacharya, S. and Kar, R. (2002) High-temperature dehydration melting and decompressive $P-T$ path in a granulite complex from the Eastern Ghats, India. Contributions to Mineralogy and Petrology, 143, 175-191.

[61] Sheraton, J.W., Tindle, A.G. and Tingey, R.J. (1996) Geochemistry, origin, and tectonic setting of granitic rocks of the Prince Charles Mountains, Antarctica. Australian Geological Survey Organisation Journal of Australian Geology and Geophysics, 16, 345-370.
[62] Hansen, E.C. and Stuk, M. (1993) Orthopyroxene-bearing mafic migmatites at Cone Peak, California: Evidence for the formation of migmatitic granulites by anatexis in an open system. Journal of Metamorphic Geology, 11, 291-307.

[63] Rushmer, T. (1991) Partial melting of two amphibolites: Contrasting experimental results under fluid absent conditions. Contributions to Mineralogy and Petrology, 107(1), 41-59.

[64] Skjerlie, K.P., Douce, A.E.P. and Johnston, A.D. (1993) Fluid-absent melting of layered crustal protolith: Implications for the generation of anatectic granites. Contributions to Mineralogy and Petrology, 114(3), 365- 378.

[65] Douce, A.E.P. and Beard, J.S. (1995) Dehydration melting of biotite gneiss and quartz amphibolite from 3 to 15 kbar. Journal of Petrology, 36(3), 707-738.

[66] Springer, W. and Seck, H.A. (1997) Partial fusion of basic granulites at 5 to $15 \mathrm{kbar}$ : Implications for the origin of TTG magmas. Contributions to Mineralogy and Petrology, 127(1-2), 30-45.

[67] Bhattacharya, S., Kar, R., Misra, S. and Teixeira, W. (2001) Early Archaean continental crust in the Eastern Ghats granulite belt, India: Isotopic evidence from a charnockite suite. Geological Magazine, 138(5), 609-618.

[68] Harris, N., Ayres, M. and Massey, J. (1995) Geochemistry of granitic melts produced during the incongruent melting of muscovite: Implications for the extraction of Himalayan leucogranite magmas. Journal of Geophysical Research, 100(8), 15767-15777.

[69] Brown, M., Rushmer, T. and Sawyer, E.W. (1995) Mechanisms and consequences of melt segregation from crustal protoliths. Journal of Geophysical Research, 100(8), 15551-15563.

[70] Vigneresse, J.L., Barbey, P. and Cuney, M. (1996) Rheological transition during partial melting and crystallization with application to felsic magma segregation and transfer. Journal of Petrology, 37(6), 1579-1600.

[71] Brown, M. and Rushmer, T. (1997) The role of deformation in the movement of granitic melt: Views from the laboratory and the field. In: Holness, M.B., ed., Deformation-Enhanced Fluid Transport in the Earth's Crust and Mantle, the Mineralogical Society Series, 8, 111-144. 